\title{
СОЗДАНИЕ ЦИФРОВОЙ МОДЕЛИ ЮРСКО-МЕЛОВЫХ ОТЛОЖЕНИЙ ЮГА ТЮМЕНСКОЙ ОБЛАСТИ
}

Речиетников A.A.

(ООО НППГМ "Геосейс")

\section{Резюме}

В докладе раскрываются общие принципы построения трёхмерной структурной модели на основе сейсмогеологической интерпретации по площадным профилям 2D. С использованием результатов сейсмогеологической корреляции по профилям 2D плопаднњх съёмок и данньгх сейсмокаротажа по скважинам была построена скоростная модель толщи юрско-меловых отложений юга Тюменской области. На основе комплекса геолого-геофизических даншых создана џнфровая структурная модель региона.

Введение

В настоящее время в ряде ведущих компаний ведутея работы по разработке методик и их программной реализации по трёхмерному геологическому моделированию, которые позволили бы по наблодёныым данным восстановить поля геологических параметров в трёхмерном пространстве.

Поскольку исходные данные мы имеем во временном масштабе, возникает необходимость их пересчёта в глубинный масптаб. В этом случае мы можем судить о геометрии геологических объектов в масштабе района изучения. Анализ глубинной геометрической модели позволит нам проследить историю геологического развития от нижних - наиболее древних до самых верхних - наиболее молодых горизонтов. Иначе говоря, историю седиментационного заполнения бассейна и его фрагментов. Далее, построенная глубинная модель, являющаяся геометрическим представлением геологических толщ, будет наполняться данными о вещественном составе и физических свойствах пород. Также эту модель можно будет наполнить палеогеографическим содержанием, что позволит осветить детали геологического строения каждой толщи.

Цель работы

Создание удобного и постоянно обновляемого средства хранения, визуализация и анализа комплексньх геолого-геофизических данных и результатов их интерпретации в рамках проекта.

Исходя из поставленной цели были сформулированы следующие задаqи:

1) Формирование базы геолого-геофизических данных и результатов их интерпретации.

2) Формирование временно-глубинной (скоростной модели).

3) Построение структурной (толстослоистой) модели региона.

4) Моделирование процессов тектонического развития и осадочного заполнения с элементами палеогеографии и палеогеоморфологии.

5) Моделирование распределения вещественньгх характеристик и физических свойств для каждого седиментационного комплекса.

В качестве исходного материала в проект был загружен следующий набор данных:

1. Сейсмопрофили 2D площадных съёмок общей протяжённостью около 25000 пог. км., значения Т0 (результаты сейсмической интерпретация по сейсмияеским профилям) по пяти опорным и 20 целевым сейсмогоризонтам.

2. Положение устьев 250 скважин, данные сейсмокаротажа по отдельным скважинам, уточнённые стратиграфктеские разбивки (маркёры).

3. Границы выклинивания и прекращения прослеживания горизонтов.

Проанализировав набор исходных данных была выбрана следуғщая схема построення скоростной модели.

На основе сейсмокорреляции конвергентным методом с сеткой 200*200 м посчитаны карты изохрон по горизонтам с учётом границ выклинивания. Далее построена объёмная скоростная модель - то есть пространство в пределах моделируемого объекта по латерали и по вертикали от ОГ А до линии приведения заполнено значениями интервальных скоростей. В качестве исходных данных использованы карты изохрон, а для распета скоростных законов - данные сейсмокаротажа по скважинам. Для контроля тодности в построение модели включены стратиграфические разбивки горизонтов по скважинам.

На выходе получилены структурные поверхности горизонтов, карты интервальных скоростей и интегрированная в проект скоростная модель, позволяющцая пересдитывать данные (например профиль ОГТ) из временного масштаба в глубинный.

Логидеским завершением работы над региональным проектом стала априорная объёмная геометрическая (структурная) модель.

Заключение.

На основе полученной модели была проанализирована история структурообразования, установлены палеогеоморфологические условия седиментации и выделены зоны наиболее вероятного развития улучшенных коллекторов в юрском и нионемеловом интервалах разреза. Эти результаты легли в основу программы геологического изучения крупных поисковых блоков в Уватском районе юга Тюменской области. 